\title{
A comparative analysis of two Early Palaeozoic marine impact structures in Estonia, Baltic Sea: Neugrund and Kärdla
}

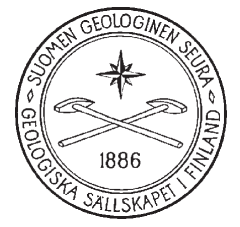

\author{
Sten Suuroja ${ }^{1,2}$, Kalle Suuroja ${ }^{1}$ and Tom Flodén ${ }^{3}$ \\ ${ }^{1}$ Geological Survey of Estonia, 12168 Tallinn, Estonia \\ 2 Department of Geology, University of Tartu, Ravila 14a 50411, Estonia \\ ${ }^{3}$ Department of Geological Sciences, Stockholm University, 10691 Stockholm, Sweden
}

\section{Abstract}

Kärdla and Neugrund are two Early Palaeozoic offshore impact structures located some $50 \mathrm{~km}$ apart along the Estonian coast of the Baltic Sea. They share many similarities but differing features are also found. The Kärdla impact structure is located at the NE coast of Hiiumaa Island $\left(58^{\circ} 58^{\prime} \mathrm{N}, 2^{\circ} 46^{\prime} \mathrm{E}\right)$. The inner crater has a $4 \mathrm{~km}$ rim-to-rim diameter and a c. $130 \mathrm{~m}$ high central uplift, surrounded by a ring fault, c. $12 \mathrm{~km}$ in diameter. The well-preserved buried inner crater is outlined in the landscape by a circular ridge of uplifted bedrock. The perimeter of the outer crater is outlined on the seafloor by a semicircular ridge of narrow shoals. The variable height of the rim wall (50-240 m above the crystalline basement level) and the asymmetric location of the inner crater is obviously a result of an oblique impact in a layered target and partial collapse of the rim wall. Shortly after the impact in a shallow epicontinental sea during Late Ordovician time (c. $455 \mathrm{My}$ ), calcareous biodetritic muds were deposited and the crater was buried. The Neugrund impact structure is located in the seabed at the entrance of the Gulf of Finland $\left(59^{\circ} 20^{\prime} \mathrm{N}, 23^{\circ} 31^{\prime} \mathrm{E}\right)$. The inner crater has a $7 \mathrm{~km}$ rim-to-rim diameter and the outer limit of the structure passes through the Osmussaar Island to the southwest of the impact centre. The crater was buried in a shallow epicontinental sea with siliciclastic deposition shortly after the impact at Early Cambrian time, c. 535 My. It was partially re-exposed by erosion during Pliocene. The target had a three-layered composition: Precambrian metamorphic rocks covered by Ediacaran and Early Cambrian siliciclastic rocks (c. 150 m) and water (c. 100 m). The structure has been studied with seismoacoustic and sidescan sonar profiling, and by diving and sampling of submarine outcrops. Several hundred samples of impact breccias have been collected and investigated from erratic boulders distributed by glacial action in the west Estonian mainland, islands and sea floor.

Keywords: impact features, impact craters, marine environment, seismic methods, sonar methods, impact breccias, quartz, planar deformation features, Paleozoic, Kärdla, Neugrund, Estonia

Corresponding author email: s.suuroja@egk.ee

Editorial handling: Joonas Virtasalo 


\section{Introduction}

In the Earth Impact Database (www.paasc.net), 183 hypervelocity impact structures are listed. Only ten of these (Bedout, Eltanin, Ewing, Lumparn, Mjölnir, Montagnais, Neugrund, Shiva, Silverpit, Tvären) are located completely on sea floor, and five (Charlevoix, Chesapeake Bay, Chicxulub, Kara, Kärdla) partially (www.paasc.net). In the Baltic Sea region, four similar structures have been found, Lumparn, Tvären, Kärdla and Neugrund. Two of them, Kärdla and Neugrund are located in Estonia.

The Kärdla meteorite impact structure, with its centre at $58^{\circ} 58^{\prime} \mathrm{N}, 22^{\circ} 46^{\prime} \mathrm{E}$, is located mostly on the NE coast of Hiiumaa Island in western Estonia, but partly in the Kärdla Bay to the northeast of the island (Fig. 1). The Kärdla impact structure was buried shortly after the impact. Therefore its structures and its complex of impact-generated deposits, including the ejecta layer, are mostly preserved today. The structure area is penetrated by numerous (162) drill holes. Thus, Kärdla is not only one of the best-preserved impact structures in the world, but also one of the best studied (Fig. 2; Fig. $3)$.

The Neugrund meteorite impact structure is located in the southern part of the entrance to the Gulf of Finland at $59^{\circ} 20^{\prime} \mathrm{N}, 23^{\circ} 31^{\prime} \mathrm{E}$. The centre of the structure is some $10 \mathrm{~km}$ to the northeast of the Osmussaar Island (Fig. 1). Thus, Osmussaar is located at the outer boundary of the impact structure. Osmussaar, in Swedish Odensholm has a prominent position in Nordic mythology. According to the legends the chief god of the Vikings, Oden (Odin in old Norse), was buried on the island (Eichwald, 1840). Before World War II, there was an erratic boulder on the island named Odens Stein and by legends this was the burial site of Odin.

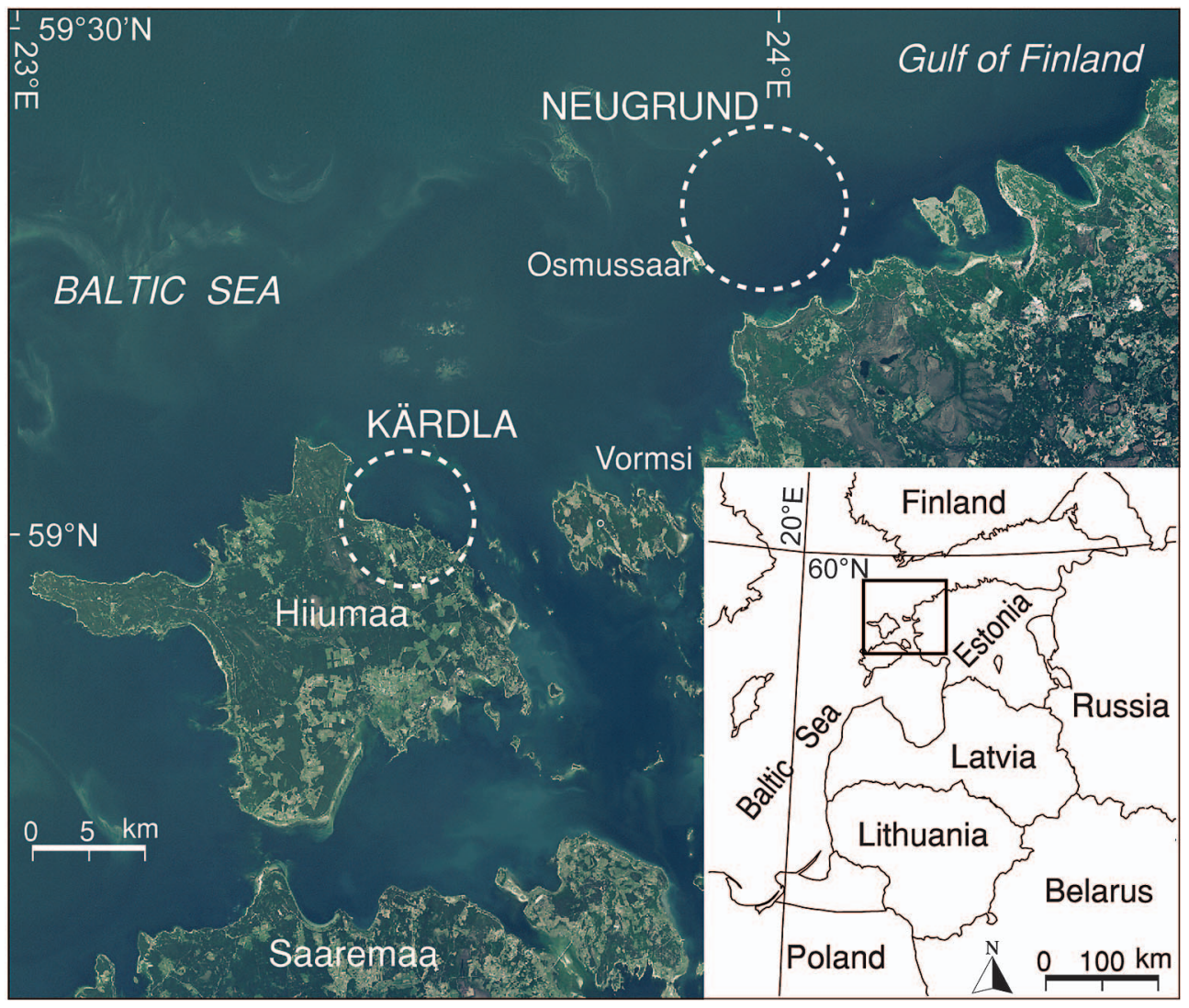

Fig.1. The Kärdla and Neugrund impact structures indicated in a satellite image. The white dashed lines mark the outer limits of the structures. 


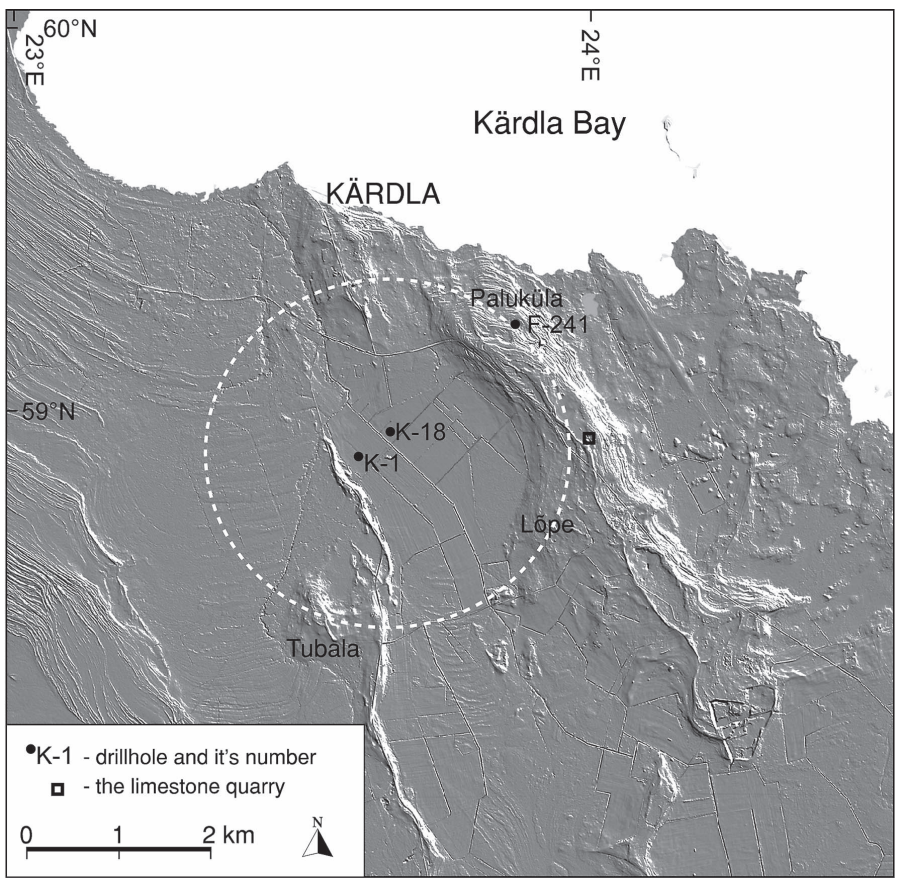

Fig.2. A LIDAR relief of the buried Kärdla meteorite crater. The white dashed line indicates the position of the ridge of the buried rim wall.

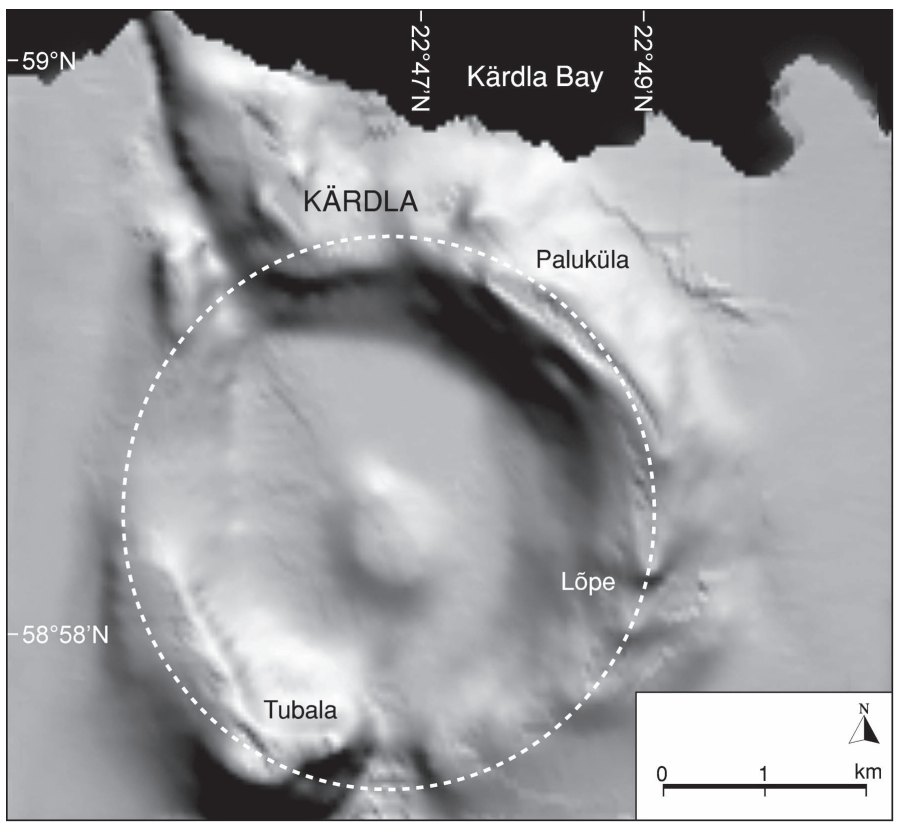

Fig.3. Shaded sedimentary bedrock relief of the central part of the Kärdla meteorite crater area. The dashed line indicates the position of the ridge of the buried rim wall.
The Neugrund structure is the bestpreserved offshore impact structure in the world. Moreover, it is the only one whose main morphological units are visible and easily accessible (Fig. 4). The geological section of the target area is well documented by data obtained mainly from the drill hole on the Osmussaar Island.

The distance between the Kärdla and Neugrund impact structures is c. $50 \mathrm{~km}$. The time interval between the two impact events is about eighty million years, them having occurred $455 \mathrm{My}$ and $535 \mathrm{My}$, respectively. The impact origin of the two structures was established by K. Suuroja et al. (1981) and K. Suuroja (1996), respectively. Experience obtained during the study of the Kärdla impact structure, namely the impact influenced rocks in the core sequences, were the guides leading to the discovery of the Neugrund impact structure.

\section{Methods and materials}

\subsection{The Kärdla impact stucture}

Tilted beds of Ordovician limestones (not a common feature in Paleozoic in Estonia) in the Paluküla Quarry on the Hiiumaa Island were described already in the $19^{\text {th }}$ century (Eichwald, 1840; Schrenk, 1854; Schmidt, 1858). Later, data on the occurrence of asphalt (Winkler, 1922; Scupin, 1927) and galena (Palmre, 1961) were published. In 1966, drilling of a well on the Paluküla Hill was stopped as Precambrian metamorphic rocks were unexpectedly met at a depth of $16 \mathrm{~m}$, instead of anticipated c. $230 \mathrm{~m}$. The revealed uplift of crystalline basement rocks was interpreted as a placanticlinal structure (Viiding et al., 1969). A nearby 


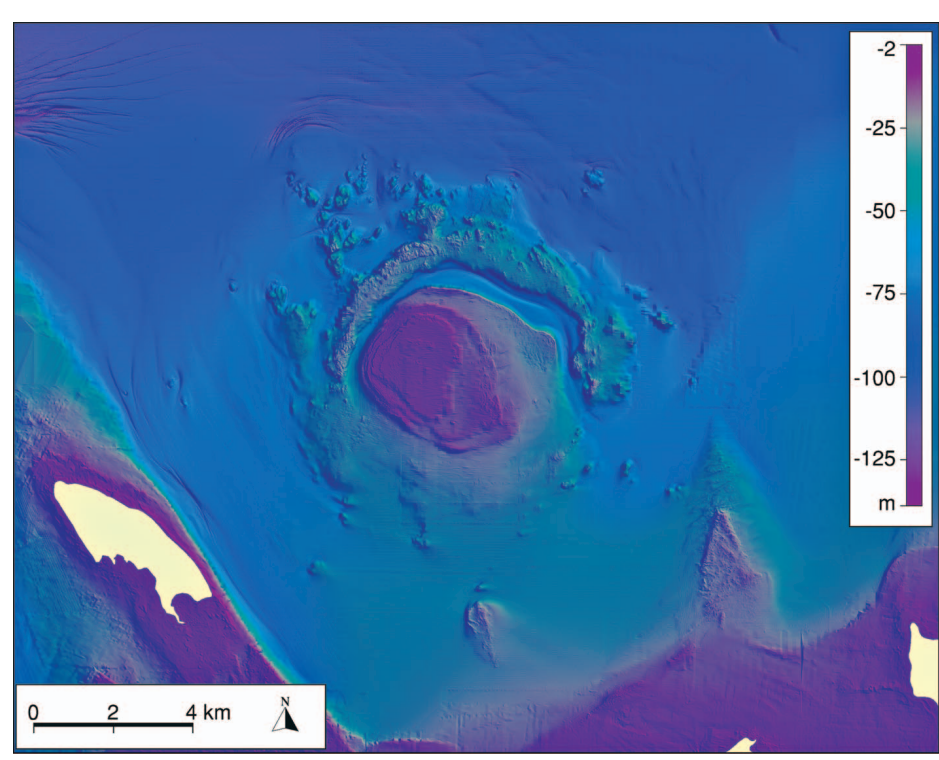

Fig. 4. The shaded relief image of seabed at the Neugrund impact structure area.

structural depression was first explained as a graben. The impact breccias that penetrated in the crater proper were interpreted as Precambrian tillites. Continued exploration of the area included detailed geophysical mapping by means of gravimetry and magnetometry and drillings of tens of wells (Puura $\&$ Suuroja, 1984). As a result, the crater structure was revealed and a hypothesis of a crypto-volcanic origin was put forward (Puura, 1974; Suuroja et al., 1974).

Impact breccias, shocked quartz and other features of shock metamorphism were found in thin sections in the late 1970's (Suuroja et al., 1981). The impact origin of the structure was recognized using these data. Subsequently, numerous wells were drilled in the course of several geological mapping and prospecting projects in the crater area (Suuroja et al., 1991, 1994). While prospecting for mineral water, the well K-18 revealed that the central uplift reached massive crystalline basement rock from depth c. $400 \mathrm{~m}$ at the end of well to $443 \mathrm{~m}$ (Puura \& Suuroja, 1992). An important feature of geophysical modelling is the lack of an observable geophysical signature of the central uplift (Plado et al., 1996). It can be ruled out that this would be a huge (more than $200 \mathrm{~m}$ in diameter) crystalline fragment (megablock), such as found in the
Chesapeake Bay drilling at Eyreville (Gohn et al., 2008). In the Kärdla case massive crystalline rocks represent the central uplift and are covered by more than $100 \mathrm{~m}$ uplifted (similar to uplifting rate of the central uplift) $c$. $50 \mathrm{~m}$ thick sequence of impact-related deposits (suevite-like breccias) (Suuroja \& Suuroja 2002). The deepest (815.2 m) well in Estonia, Soovälja K1 , was drilled within the annular crater depression (Suuroja \& Póldvere, 2002). The well reached the crater floor at the depth of $523 \mathrm{~m}$, but continued through autochthonous impactinfluenced (fractured, with a thin lens of breccias) crystalline basement metamorphic rocks to the bottom of the well. A total of 162 drill holes were drilled, revealing new information on the crater structure, deposits and ejecta layer. Among them, 46 wells reached the impact breccias and the crystalline basement rocks, 64 wells reached the distal ejecta blanket or dislocated pre-impact target rocks, six wells reached the sub-crater basement inside of the crater proper (Puura et al., 2004; Suuroja and Suuroja, 2004).Continuous seismic reflection profiling along the northeastern margin of the Kärdla structure in the Kärdla Bay was made in 1996. It established the existence of the previously assumed ring fault (Suuroja et al., 2002). Along the outer slope of the crater wall, a sulphide ore with concentrations of galena and sphalerite was observed at the contact between the impact-influenced Early Cambrian sandstone and the covering Ordovician limestones (Suuroja et al., 1991; Suuroja, 2002). The c. $5 \mathrm{~m}$ thick ore body distinguished in the northeastern slope of the Paluküla Hill at a depth of c. $40 \mathrm{~m}$ contained up to $10 \%$ of zinc, and up to $2 \%$ of lead. Solid black asphaltite was found in the fractures and pores of the Ordovician limestones in the crater, as well as brownish blotches impregnated with liquid oil in argillaceous carbonate rocks. The latter are connected with a hydrocarbons inflow captured by the impact structures at Late Ordovician time (Kattai et al., 1990; Suuroja, 2001). 


\subsection{The Neugrund impact structure}

Early in the 20th century, Öpik (1927) and Thamm (1933) described a breccia-like rock, a gneiss-breccia, from large erratic boulders found in the coastal area of NW Estonia and Osmussaar Island. Later the gneiss-breccia boulders were described by Orviku (1935) and Viiding (1955), but the origin of the boulders was not discussed. In the course of geological mapping in NW Estonia, the upper part of the Early Cambrian sequence was found to contain intervals of brecciated clay- and sandstone (Kala \& Eltermann, 1969; Suuroja et al., 1987). It was later noted (Suuroja \& Saadre, 1995) that the gneiss-breccias are macroscopically very similar to the clast-supported impact breccias found in the drill core sections of the Kärdla meteorite crater. They suggested that the erratic boulders of gneiss-breccia were supposedly glacially transported from an impact structure located in the Neugrund Bank area.The surroundings of the Neugrund Bank were investigated in Estonian-Swedish marine geological co-operation for the first time in 1996 by seismic reflection profiling and sediment soundings (Fig. 5). The seismic data was recorded in the frequency band of $250-500 \mathrm{~Hz}$, and the sediment sounder data at $4 \mathrm{kHz}$. The profiling revealed a crater-like structure with a c. $7 \mathrm{~km}$ rim-to-rim diameter. Suuroja (1996) presumed the impact to have occurred in the Early Paleozoic (c. 475 My). Somewhat later, quartz grains with PDFs (planar deformation features) were found in the gneiss-breccias, which made the impact origin of the structure even more probable (Suuroja et al., 1997). In 1998, samples were collected by scuba divers from the submarine outcrops of brecciated Precambrian metamorphic rocks, and quartz grains with PDFs were found. Herewith, the impact origin of the Neugrund structure was proved (Suuroja \& Suuroja, 1999, 2000).

During fifteen years in 1998-2012, the Neugrund impact structure area was the subject of sixteen marine expeditions, using seven separate research vessels (Mare, Marina and Salme from Estonia, Strombus and Skagerak from Sweden, Humboldt and Littorina from Germany). R/V Mare of the Estonian Maritime Museum has participated in nine expeditions and all scuba diving has been done from this ship. The total number of diving sites is 25 . Submarine sequences of bedrock were documented and sampled along the edge of the central plateau at the depth 2-46 m during scuba diving. Impact influenced Precambrian metamorphic rocks were

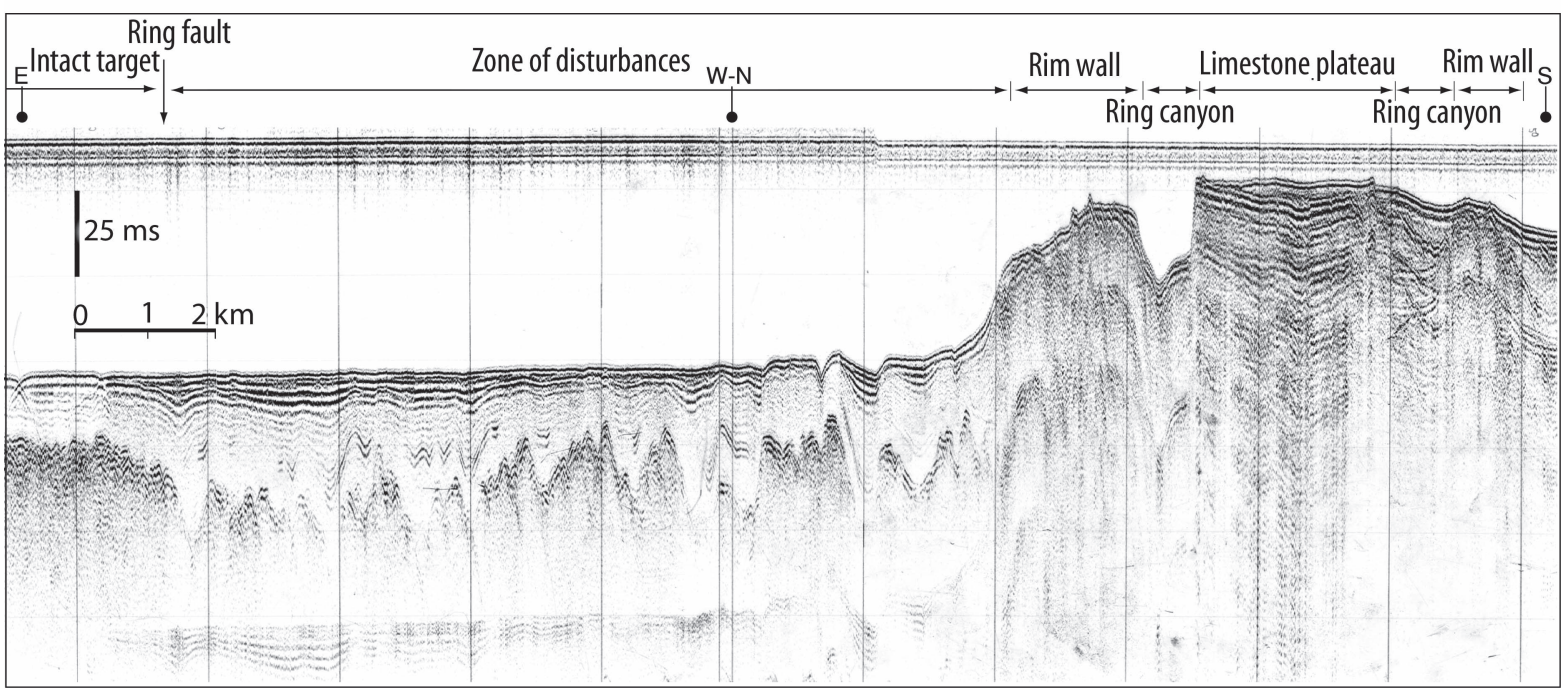

Fig. 5. N-S direction seismic reflection profiling record across the Neugrund structure carried out in 1996 on board of the R/V Strombus. Space between vertical lines 10 minutes or c. $1.8 \mathrm{~km}$. The recorded signals are filtered frequency band 250-500 Hz using a single channel Air-gun system. 


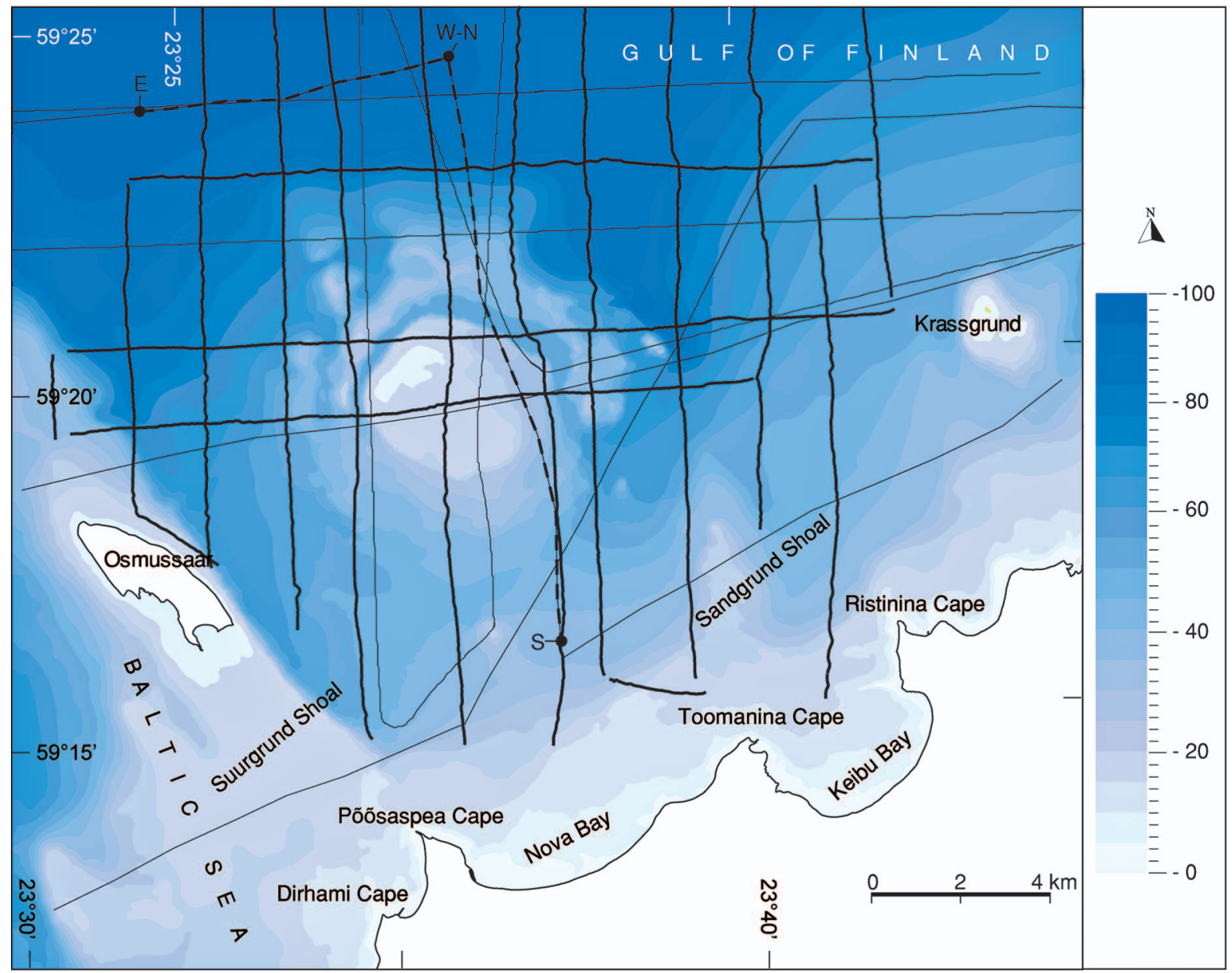

Fig. 6. Seabed relief of the Neugrund meteorite crater area. The thinner lines indicate the location of seismic reflection profiles shot in 1996-2004. The thick lines indicate the location of seismic (PAR) reflection profiles shot in 2010.

likewise documented and collected along the rim wall and the zone of dislocations at the depth of 16-34 m (Fig. 7).

As a rule, the exposures were recorded by a Sony camcorder accommodated with ikelite underwater systems during diving. Additionally, submarine outcrops were observed using a remote operated vehicle (ROV) camera system SeaLion and sidescan sonar. The diving sites include: 1) the limestone sequence of the central plateau and the crater infill from the precipice, 2) the impact influenced Precambrian metamorphic rocks of the rim wall, 3) impact influenced Precambrian meta-

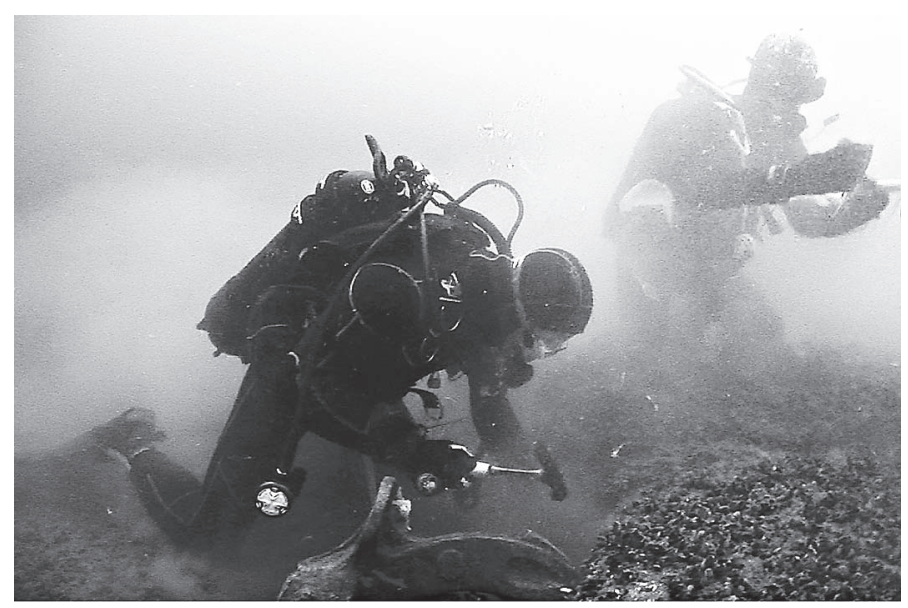

Fig. 7. Geologist scuba diver sampling a submarine outcrop of Precambrian metamorphic rocks. 
morphic rocks of erratics located inside the zone of dislocations, 4) submarine outcrops of post-impact sedimentary rocks in surroundings of the crater.

Seismic reflection profiling is the most extensively applied method for the investigation of the structure, in total approximately $1000 \mathrm{~km}$ of profiles were shot. Most of them (c. $400 \mathrm{~km}$ ) were shot in 2010 (Fig. 6). A grid of 20 profiles with average lengths of $20 \mathrm{~km}$ were shot across the structure during this expedition. The profiling was performed using a single-channel Airgun system, PAR-600 at $12 \mathrm{MPa}$. The recorded signals were frequency filtered $250-500 \mathrm{~Hz}$ in order to penetrate the sedimentary bedrock to the basement with high resolution. The Chirp spread spectrum (CSS) technique was simultaneously used to obtain highresolution records of the Quaternary deposits. The Edge Tech low-frequency $(0.5-12 \mathrm{kHz})$ sub-bottom profiler was used.

\section{Geological setting}

At Kärdla, as well as at Neugrund, the meteorite hit the seabed at sites with rather similar regional geological setting, the Early Palaeozoic Baltic epicontinental basin on the East European Craton. The basin extended across the present Russian Platform and also covered large parts of the neighbouring Fennoscandian Shield. At both sites, Precambrian migmatized metamorphic rocks underlie the sedimentary (mainly siliciaclastic) rocks. Consequently, the allochthonous impact breccias are composed of a mix of sedimentary and metamorphic rocks. Also, at both sites, the crater extended through the sediments and into the topmost part of the crystalline basement rocks. The basement rocks belong to the c. 1.9 Gy old Paleoproterozoic Orosirian Period of the Svecofennian Crustal Domain (Kirs et al., 2009). In both areas the Svecofennian crust is about $45 \mathrm{~km}$ thick (Puura \& Flodén, 2000). The metamorphic rocks are found in the polymict breccias, and in huge allochthonous brecciated boulders near the main crater structures. They are similar to the crystalline basement rocks drilled in the surroundings of both crater sites. Both crater structures, that formed in the sea basin, were soon (probably within a few million years) buried under sediments.

In Kärdla, the meteorite struck in a shallow epicontinental sea where at that time bioclastic limy muds were deposited (Fig. 8). According to different authors various water depths at the impact site have been proposed: 20 m (Puura \& Suuroja, 1992), c. $50 \mathrm{~m}$ (Suuroja et al., 2002), 50-100 m (Lindström et al., 1992), c. $100 \mathrm{~m}$ (Suuroja \& Suuroja, 2006), more than $100 \mathrm{~m}$ (Suuroja, 2008).

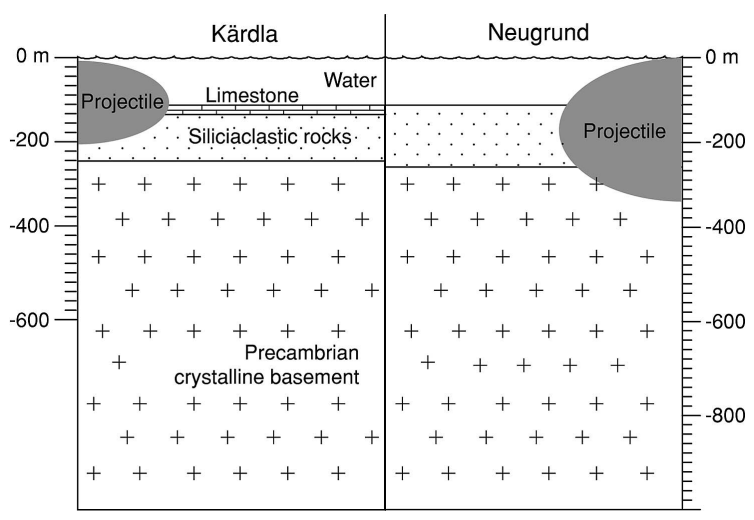

Fig. 8. Setting of the targets and projectiles of the Kärdla and Neugrund meteorite impacts.

Shuvalov (2002) demonstrated by numerical modelling of impacts in shallow sea areas that if the water depth is less than $100 \mathrm{~m}$, the resurge initiated by the impact cannot be strong. However, based on the quantity of the resurge breccias in the Kärdla crater, it was relatively strong. Probably, ample quantity of resurge breccias is associated with the collapse prior to the entry of the resurge (Sturkell et al., 2013).

The criteria for estimation of sea depth at impact sites emit from the pre-impact sedimentation facies signatures. Ainsaar et al. (2002) proposed that the water depth in a crater area, where bioclastic argillaceous-calcareous limy mud are deposited, may vary from some tens of meters (i.e. below level of the storm waves in epicontinental seas) down to more than $200 \mathrm{~m}$.

At present, the thickness of the pre-impact sedimentary bedrock in the area is c. $140 \mathrm{~m}$. Middle 

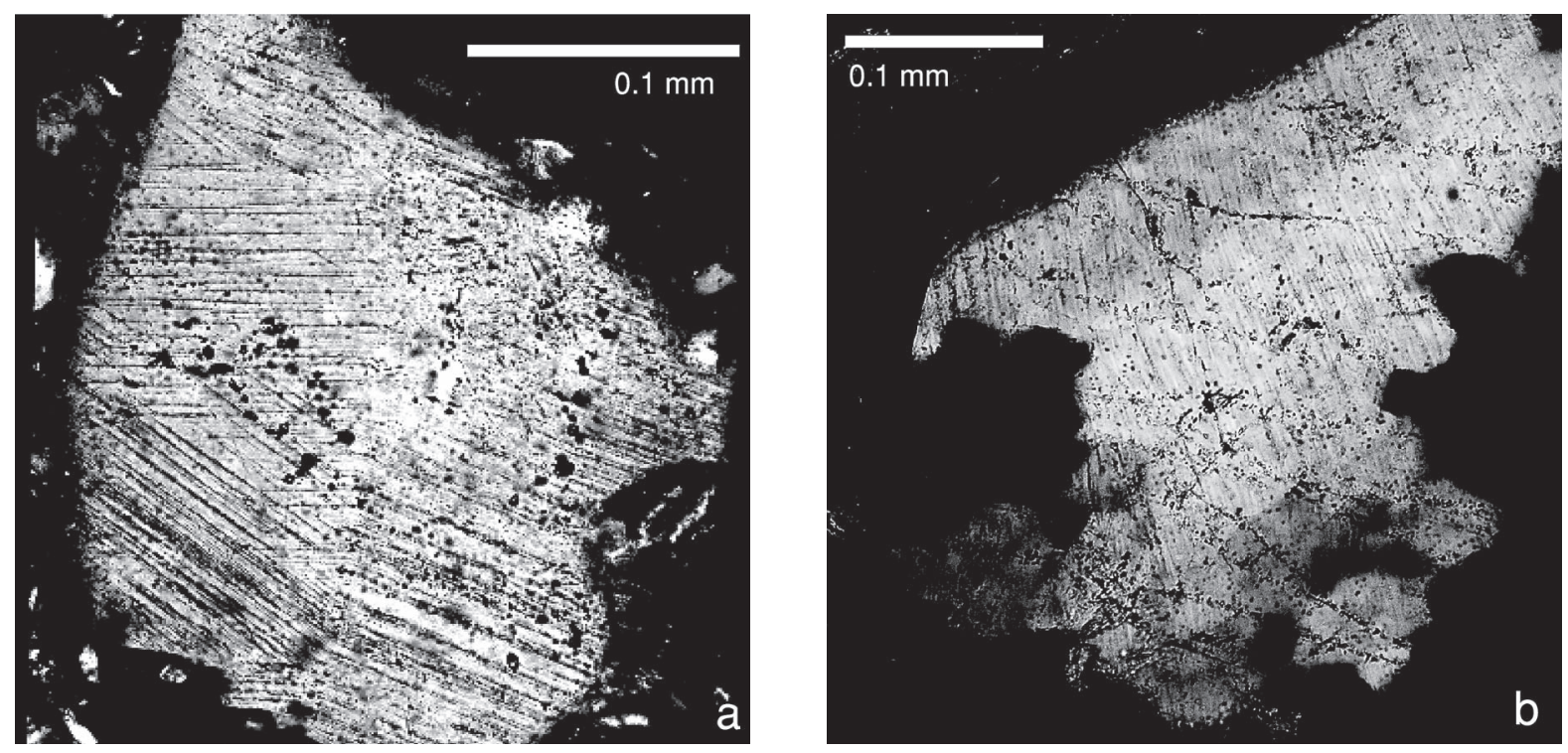

Fig. 9. Shock-metamorphosed quartz grains (PDF-quartz) with multiple PDFs from the impact related rocks of the Kärdla and Neurund impact structures. (a) Quartz grain with 3 sets of slightly decorated PDFs. Sample from a matrix supported impact breccia of Kärdla crater. Thin-section, cross-polarised light. (b) Quartz grain with 3 sets of slightly decorated PDFs. Sample from a vein of matrix supported impact breccia from the brecciated crystalline basement rocks of the Neugrund crater. Thin-section, cross-polarised light.

Ordovician limestones form the uppermost $14 \mathrm{~m}$ of this complex. The next subjacent $8 \mathrm{~m}$ are composed of Lower Ordovician weakly lithified sandstones (glauconite sandstone and Obolus or detritic sandstone) and alum (graptolite) shale. The Ordovician unit is underlain by an about $120 \mathrm{~m}$ thick complex of weakly lithified Lower Cambrian sandstones, siltstones and clays. At the time of the impact, the sandy and silty sequence was less consolidated and therefore much thicker than at present. The topmost part of the crystalline basement $(5-25 \mathrm{~m})$ is weathered and rocks are enriched with the secondary minerals illite and kaolinite. At the Kärdla site, the polymict impact breccias are composed of three main lithological types: 1) carbonate rocks, 2) siliciclastic to clayey sedimentary rocks, and 3) a variety of crystalline rocks. At the Neugrund site, mainly crystalline rockderived clastic breccias are found now. Magnetic modelling (Suuroja et al., 2002) indicates that impact breccias are expected to be present in the crater deep (Fig. 10; Fig. 11).

In the Neugrund case the cross-section of the target is best documented by the nearest well that is located on the Osmussaar Island and penetrates all rocks of the pre-impact target (Suuroja and Suuroja, 2000). A c. $150 \mathrm{~m}$ thick layer of unconsolidated fine-grained siliciclastic sediments covered the Precambrian crystalline basement at the time of the impact. Presently the compacted c. $100 \mathrm{~m}$ thick preimpact succession is composed of Early Cambrian sandstones, siltstones and clays of the Lontova Formation (c. $40 \mathrm{~m}$ ) on top of a complex of weakly lithified quartzose sandstones $($ c. $60 \mathrm{~m}$ ) of the Neoproterozoic Ediacaran Period.

The depth of the sea, where the blue clay with interlayers of silt and fine- to middle grained quartz sand was deposited, is estimated to have been 50100 m (Suuroja \& Suuroja, 1999).

\section{Age of the structures}

The ages of the Kärdla and Neugrund impact structures are determined by biostratigraphic dating of the distal ejecta layers inside of marine sedimentary record of the Upper Ordovician and Lower Cambrian sequence, respectively. In Kärdla, where the ejecta layer is represented by a sandy 


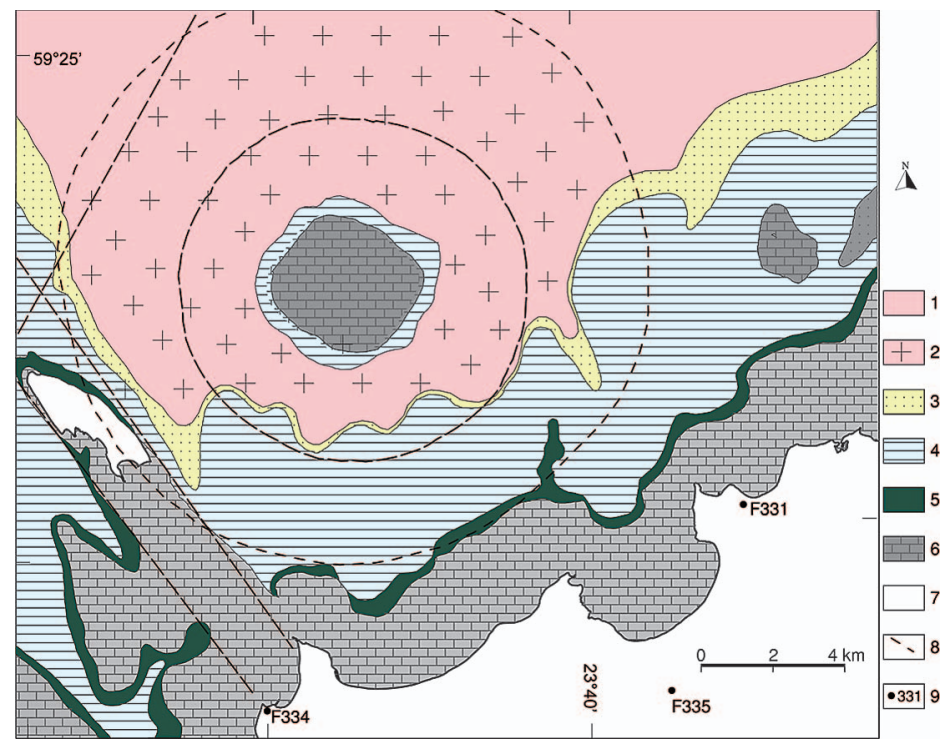

Fig. 10. Schematic bedrock geological map of the Neugrund impact structure area. Legend: 1 - Precambrian (Orosirian) metamorphic rocks; 2 - impact disturbed Precambrian metamorphic rocks; 3 - preimpact (Ediacaran and Lower Cambrian) siliciclastics (clay-, silt- and sandstones); 4 - post-impact Lower Cambrian siliciclastics (clay-, silt- and sandstones); 5 - Lower Ordovician siliciclastics (sandstones and alum shale); 6 - Ordovician limestones; 7 - Land; 8 - Fault; 9 - Drill hole and it's number.
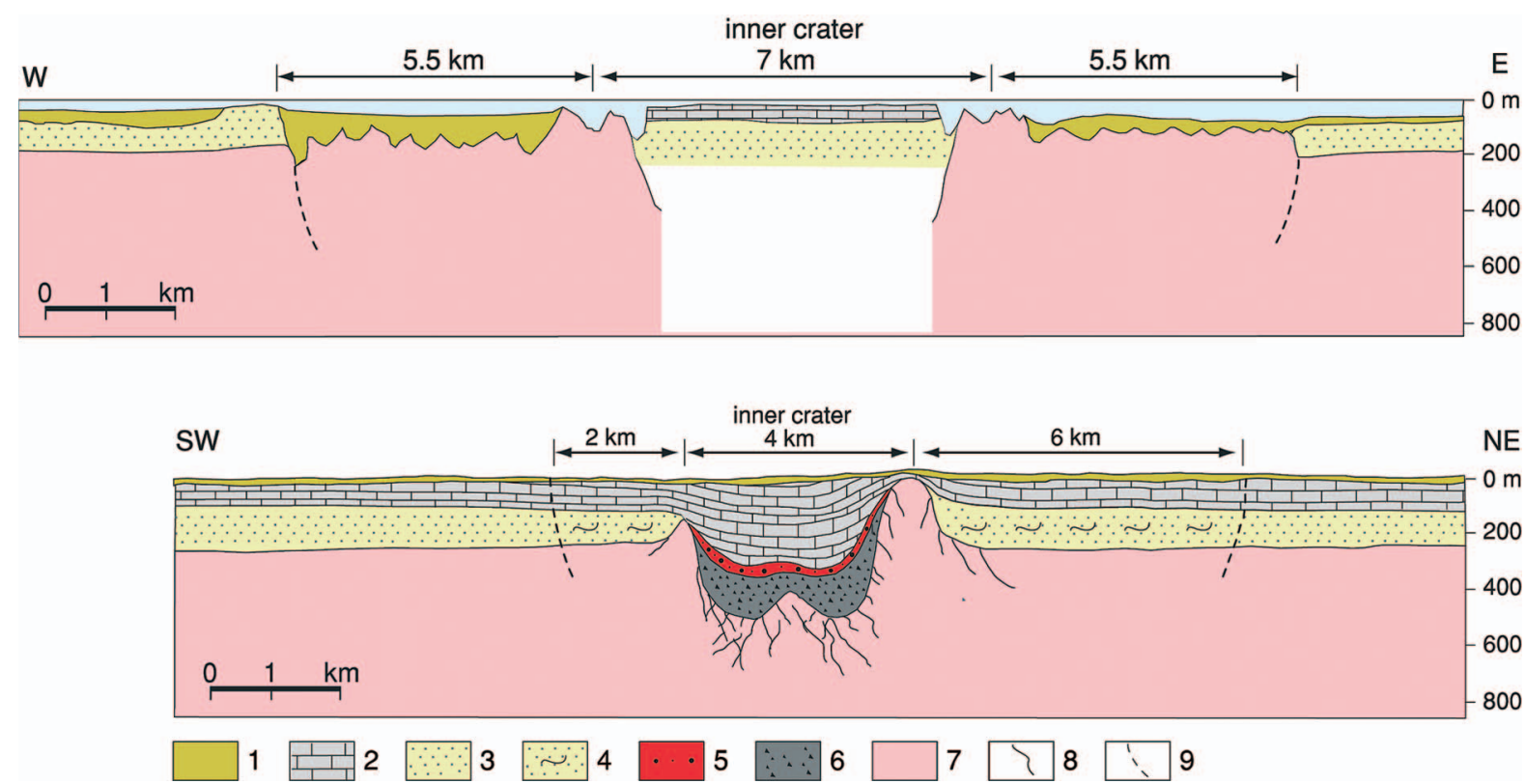

Fig. 11. Comparative schematic west-east gross-sections of the Kärdla (lower) and the Neugrund (upper) impact structures. Legend: 1 - Quaternary deposits; 2 - Ordovician limestones; 3 - Ediacaran and Lower Cambrian siliciclastics (clay-, siltand sandstones); 4 - Disturbed Ediacaran and Lower Cambrian siliciclastics; 5 - Crater filling siliclastics; 6 - Impactrelated deposits (impactites); 7 - Precambrian (Orosirian) metamorphic rocks; 8 - Fractures; 9 - Supposed ring fault.

interval in the limestone sequence, it is well defined. In Neugrund, where the distal ejecta are represented by a sandy layer inside of a sequence of Early Cambrian sandstones, it is more difficult and possible only by the findings of quartz grains with PDFs (Suuroja \& Suuroja 2004) (Fig 9). Small crystalline fragments are very rare.

The age of the Kärdla impact was established using the stratigraphic position of the sandy ejecta layer inside the limestone sequence. The estimated level of the ejecta layer was the lowermost part of the Idavere time, Caradoc Age, Upper Ordovician 
Epoch (Suuroja et al., 1974). Bauert et al. (1987) suggested the same age of the impact using biostratigraphical dating of the distal ejecta layer in the chitinizoan zonality of the continuous sequence of the Ordovician carbonate sediments. Grahn et al. (1996) determined the precise level of the ejecta to be above the occurrence of Cyathochitina cf. Reticulifera, but below the appearance of "Eremochitina" dalbyensis (Laufeld). This level corresponds to the lowermost Diplograptus multidens graptolite zone. The determined level corresponds to the absolute age of about $455 \mathrm{My}$ (Upper Ordovician, Katian Age) in the International Stratigraphic Chart.

The Neugrund impact event was initially suggested (Suuroja, 1996; Suuroja et al., 1997) to be connected to the about $475 \mathrm{My}$ old so called Osmussaar-breccia, which consists of breccia-like sandstone dykes that crop out on the Osmussaar and Suur-Pakri islands. Dykes are also present in some drill holes on the NW Estonian mainland inside of a c. $1 \mathrm{~m}$ thick Middle Ordovician limestone sequence. The oldest rock sampled from the infilling deposits of the crater proper was collected from a water depth of $46 \mathrm{~m}$. The sample consists of Early Cambrian sandstone of the Tiskre Formation and is at least about 530 My old (Suuroja \& Suuroja, 2000). Probably the real age of the crater is better estimated by the ejecta layer above of the blue clays of Lontova Formation (Early Cambrian Terreneuvian Epoch). The c. $2 \mathrm{~m}$ thick ejecta layer has been studied at a distance of $13 \mathrm{~km}$ from the impact centre (Suuroja \& Suuroja, 2004). Biostratigraphically the deposits reflecting the impact event belong to the pre-trilobite Early Cambrian Platysolenites antiquissimus biozone of the East-European Craton.

\section{Morphology of the structures}

Kärdla and Neugrund complex impact structures have principally quite similar morphology. The inner craters (diameter 4 and $7 \mathrm{~km}$, respectively) are surrounded by about three times larger (diameter 12 and $18 \mathrm{~km}$, respectively) outer structure, or rather, zones of disturbances. In the case of the
Neugrund structure, the inner crater and the outer structure bounded by the ring fault are positioned more or less symmetrically, whereas in Kärdla the centre of the inner crater is offset about $2 \mathrm{~km}$ to the north-east. The rim walls of both the Kärdla and Neugrund craters is composed of brecciated and impact-tectonically uplifted blocks (structural uplift) of crystalline basement rocks.

The Kärdla and Neugrund impact structures are rather similar to the Ries Nördlingen (Germany) and Gosses Bluff (Australia, Northern Territory) impact structures. The Ries impact structure, which is about 14,5 My old and has an outer diameter of c. $24 \mathrm{~km}$ and a c. $8 \mathrm{~km}$ wide inner crater (Engelhardt et al., 1995). The some $142 \mathrm{My}$ old Gosses Bluff crater has c. $6 \mathrm{~km}$ wide inner crater and a total diameter of c. $22 \mathrm{~km}$ (Milton et al., 1996). The outer zone, which in Kärdla and Neugrund is interpreted as a zone of dislocations, is in Ries known as a zone of megablocks. In both cases the zones are characterized by the occurrence of deformed megablocks of crystalline and sedimentary target rocks. In Ries, all outcrops are concentrated to the outer limit of the structure, whereas in Neugrund the submarine outcrops are connected with the internal rim wall (Table 1).

The Kärdla concentric impact structure is about $12 \mathrm{~km}$ in diameter and has an inner crater rim-torim diameter of about $4 \mathrm{~km}$. The outer limit of the structure, as marked on the seafloor by a semicircular ridge of narrow shoals, and on land by a semicircular ridge of glaciofluvial hillocks. The preserved rim wall of Precambrian metamorphic rocks has been uplifted 50-250 $\mathrm{m}$ higher than the crystalline basement in surroundings. It is higher in the northeastern segment of the rim (the so called Paluküla segment). The rim is marked in relief by bedrock uplift along a line of villages, Kärdla, Paluküla, Lópe, Ala and Tubala (Figs. $2 \& 3$ ). The rim wall is about $1 \mathrm{~km}$ wide. The well F241 (Fig. 2 ), drilled on the topmost part of the rim wall on the Paluküla Hill, penetrated a complex of Precambrian metamorphic rocks, which are fractured and at times cut by the dykes of impact breccias, within c. 240 meters. Only above of the gullies the rim wall is up to $200 \mathrm{~m}$ lower. The outer wing of 
Table 1. Kärdla and Neugrund complex impact structures and other similar structures in the world.

\begin{tabular}{|c|c|c|c|c|c|c|c|c|}
\hline $\mathrm{Nr}$ & $\begin{array}{l}\text { Name of } \\
\text { the structure } \\
\text { (location) }\end{array}$ & Country & $\begin{array}{l}\text { Composition } \\
\text { of target }\end{array}$ & $\begin{array}{l}\text { Diameter } \\
\text { of structure } \\
\mathrm{km}\end{array}$ & $\begin{array}{l}\text { Diameter } \\
\text { of inner } \\
\text { crater, km }\end{array}$ & $\begin{array}{l}\text { Ratio of } \\
\text { diameters } \\
\text { of the } \\
\text { structures } \\
\text { crater }\end{array}$ & $\begin{array}{l}\text { Age, } \\
\text { My }\end{array}$ & References \\
\hline 1 & Kärdla & Estonia & Mixed & 12 & 4 & 3 & 455 & Puura \& Suuroja, 1992 \\
\hline 2 & Neugrund & Estonia & Mixed & 18 & 7 & 2.6 & 535 & Suuroja \& Suuroja, 2004 \\
\hline 3 & Ries Nördlingen & Germany & Mixed & 24 & 8 & 3.0 & 14.5 & Englehardt et al., 1995 \\
\hline 4 & Gooses Bluff & Australia & Sedimentary & 22 & 6 & 3.6 & 142 & Milton et al., 1996 \\
\hline 5 & Miölnir(Barents Sea) & Norway & Mixed & 40 & 16 & 2.5 & 142 & Dypvik et al., 2006 \\
\hline 6 & Lawn Hill & Australia & Mixed & 18 & 8 & 2.2 & 515 & $\begin{array}{l}\text { Shoemaker \& Shoemaker, } \\
1996\end{array}$ \\
\hline 7 & $\begin{array}{l}\text { Shoemaker } \\
\text { (Teague Ring) }\end{array}$ & Australia & Crystalline & 30 & 12 & 2.5 & 570 & $\begin{array}{l}\text { Shoemaker \& Shoemaker, } \\
1996\end{array}$ \\
\hline 8 & Clearwater West & Canada & Crystalline & 32 & 12 & 2.7 & 290 & Simonds et al., 1978 \\
\hline 9 & Mistastin & Canada & Crystalline & 28 & 8 & 3.5 & 35 & Robertson \& Grieve, 1975 \\
\hline 10 & Upheavel Dome & USA & Sedimentary & 10 & 3 & 3.3 & 170 & Kenkmann et al., 2005 \\
\hline 11 & Oasis & Libya & Sedimentary & 18 & 5 & 3.6 & 120 & Koeberl, 1994 \\
\hline 12 & Aorounga & Chad & Sedimentary & 13 & 5 & 2.6 & 515 & Koeberl, 1994 \\
\hline 13 & Araguainha & Brasil & Mixed & 40 & 13 & 3.1 & 245 & Crosta, 2004 \\
\hline 14 & Serra da Gangalha & Brasil & Mixed & 12 & 3 & 4.0 & 300 & Romano \& Crosta 2004 \\
\hline 15 & Vargeao Dome & Brasil & Mixed & 12 & 4 & 3.0 & 70 & Crosta, 2004 \\
\hline
\end{tabular}

the crystalline rim is at least locally overthrusting the disturbed Early Cambrian clay- and sandstone strata (Puura \& Suuroja, 1992). These strata are most intensely deformed in the near-rim zone, containing isolated large blocks of crystalline rocks. The zone of dislocations, also named the outer crater, is $2-6 \mathrm{~km}$ wide. The sedimentary targets rocks within this zone, especially the Cambrian siliciclastic rocks, are deformed, i.e. fractured and folded. Occasional blocks of crystalline basement rocks occur there as well, especially close to the rim wall. The limit of the target deformation is bounded by the ring fault. The asymmetric location of the inner (nested) crater and the ring fault, as well the variable height of the rim wall, may be the result of an oblique impact in a layered target and possible slumping of sections of the wall (Sturkell et al., 2013).

The Kärdla crater has a central uplift that is at least $130 \mathrm{~m}$ high and about $800 \mathrm{~m}$ in diameter. Jôeleht argues (personal communication) that on the basis of data obtained in seismic reflection investigation the central uplift must be somewhat higher and that its centre is located a couple of hundreds meters northeastward from the well K18 that was formally suggested to be the centre of the structure.

The Neugrund impact structure forms a prominent shoal area on the seafloor, the Neugrund Bank. The some $5 \mathrm{~km}$ wide bank area that covers the crater proper consists of limestone at the surface. The about $7 \mathrm{~km}$ wide rim wall of the inner (nested) crater surrounds it. The rim wall forms a semicircular ridge of roche moutonnées (or sheepbacks). The outer limit of the structure has a diameter of about $18 \mathrm{~km}$. As there are no exposures, and as the water is too shallow for the seismic profiling method to reach deep enough, presence of a central uplift inside of the crater, which a crater of the size of Neugrund should have, has not been proven yet. Deformed sedimentary target rocks (Ediacaran and Early Cambrian siliciclastics) and huge (up to 0,5 $\mathrm{km}$ diameter) blocks of deformed crystalline basement rocks occur within the outer part of the structure. These crystalline blocks are mapped with seismic reflection and side scan sonar profiling, and also sampled and documented by diving geologists. The ring fault encircling the outer crater is 
considered as the outer limit of the structure. In the western and northwestern parts of the structure it is expressed as an up to $80 \mathrm{~m}$ high escarpment in crystalline target rocks. In the eastern and southern parts of the crater the limit is not so clear. It is expressed there by a fault zone or by an up to $20 \mathrm{~m}$ high escarpment in crystalline target rocks. The preserved rim wall, which crops out in the northern segment but is partially buried in the southern segment, consists of crystalline basement rocks. It is about $1 \mathrm{~km}$ wide and approximately $150 \mathrm{~m}$ high.

\section{The geophysical fields of the structures}

The Kärdla impact structure appears clearly on gravity, ground maps and aeromagnetic maps. Data for these maps have been recorded at a scale of 1:50 000 (Suuroja et al., 1991; Plado et al., 1996, 1999). The maps show negative anomalies over the crater depression that is filled with low-density (average $2.4 \mathrm{~g} / \mathrm{cm}^{3}$ ) and practically non-magnetic sedimentary rocks. Positive anomalies correspond to the rim wall consisting of magnetic crystalline rocks of higher density (average $2.7 \mathrm{~g} / \mathrm{cm}^{3}$ ). On the gravity (Bouguer) map, the crater appears as a pronounced wall against the background of the rather monotonous gravity field of the Hiiumaa Island. On the large-scale gravity (residual) anomaly map, where effects of deep-seated sources have been removed, height differences within the rim wall, as well as the lower areas in its northern and southern parts are clearly visible. As visible anomalies along the ring fault do not occur, we assume that the mass dislocations between the rim wall and the ring fault are mostly present in the sedimentary cover, but do not reach substantially the crystalline basement.

The Neugrund impact structure does not appear clearly on the aeromagnetic maps. Gravity maps for that area have not been compiled and therefore size of gravity anomaly evoked by the impact is not revealed. On the other hand, the Neugrund structure is well investigated by seismic reflection and magnetic methods, the volume of the crater proper by magnetic modelling (Suuroja et al., 2002). The latter was supported by petrophysical data of samples collected from the crater rim and erratic boulders derived from the structure area.

\section{The projectiles}

The Neugrund and Kärdla impact structures belong obviously to a group of a number of Early Paleozoic meteorite craters limited to the Baltic Sea and its surroundings of about $1000000 \mathrm{~km}^{2}$ (Puura \& Plado, 2005). Apart from Neugrund and Kärdla, the group includes: Suvasvesi North (560-530 My, diameter (D) 4 km; Pesonen, 1996); Söderfjärden (540-520 My, D 6.6 km; Lehtovaara, 1992), Granby (c. 410 My, D 2 km; Alwmark, 2009); Lockne (458 My, D 7.5 km; Lindström et al., 1996) and a small crater Tvären (457 My, D 2 km (Lindström et al., 1994). This is one of the largest concentrations of impact structures of the 550-450 My age group. It has recently been speculated (e.g. Schmitz \& Alwmark, 2006; Schmitz \& Häggeström, 2006) that these and dozens (Korochantseva et al., 2007) of other Early Paleozoic craters on Earth might be a result of collapse of a huge (more than $100 \mathrm{~km}$ in diameter) L-chondritic chromite-rich asteroid. The latest geochemical research (Puura et al., 2004) revealed that the Kärdla meteorite most probably was of chondritic composition. According to the geochemical composition of the impact breccias (Suuroja and Suuroja, 2000) the Neugrund impact structure is similar to Kärdla. Melosh (1989) argues that the diameter of a crater should be approximately 20 times larger than diameter of a projectile. According to Ormö et al. (2013), this scaling is made for craters in a homogenous target not a concentric impact structures formed in a layered target where weaker sediments rocks covered a hard crystalline basement rocks. Therefore, the diameters of the Kärdla and Neugrund craters should be c. 4 and c. $7 \mathrm{~km}$ and the diameters of the projectiles c. $200 \mathrm{~m}$ and c. $350 \mathrm{~m}$, respectively.

\section{The ejecta layers}

The ejecta layers have survived at some distance from the rim wall in the Kärdla and Neugrund impacts. In Kärdla, where the sandy bed presents the ejecta 
layer in the limestone sequence, it is easily recognizable, but in Neugrund, where we have the sandy layer in the sandy sequence, it is distinguished only by the findings of PDF-quartz.

In Kärdla, the ejecta layer is composed of debris of both crystalline (metamorphic) and sedimentary (siliciclastic and carbonate) rocks. Fragments of crystalline rocks are found as far as c. $20 \mathrm{~km}$ from the crater centre, and chips of sedimentary rocks, limestones, alum shale and Cambrian clays, at 15 $\mathrm{km}$. In the ejecta composition, there is always a portion of fine-grained sandy, silty and clayey material derived from disintegrated Cambrian and Ordovician sedimentary rocks. From the distance of $20 \mathrm{~km}$ and up to as far as $40 \mathrm{~km}$, the impactrelated siliciclastic layer cemented by carbonates is composed only of sandy to clayey material. The ejected matter contains PDF-quartz (Suuroja and Suuroja, 2006).

In Neugrund, where the ejecta layer it is presented mostly by the sandy bed in the sandy succession, determination is more difficult and established only by means of findings of PDF-quartz. At first the ejecta layer was distinguished in the c. $2 \mathrm{~m}$ thick quartzose sandstone layer in Early Cambrian siliciclastic deposits (silt- and sandstones of the Sorru Formation) in the core section of F331 (Ristna, Fig. 10), which is located about $15 \mathrm{~km}$ from the impact centre to south-east (Suuroja \& Suuroja, 2006).

\section{The PDF-quartz}

The findings of PDF-quartz were one of the important evidences in proving of the meteoritic origin of the Kärdla (Suuroja et al., 1981) and Neugrund (Suuroja et al. 1997) impact structures (Fig. 9). PDF-quartz is widespread in Kärdla in suevite-like and clast and matrix-supported impact breccias, which are distinguished in the crater proper. PDF-quartz occurs also, but rarely, in the post-impact siliciclastic and quartz grains containing carbonate rocks. Generally, quartz with PDFs is not found in brecciated sub-crater and rim wall. Quartz with PDFs is considerably rare in blocks of crystalline basement rocks and allochthonous breccias. However, it is common in rounded quartz grains of clast and matrix-supported impact breccias. Quartz with PDFs is rare in the sedimentary polymict breccias in the crater deep, which consist mainly of brecciated Cambrian siliciclastic rocks, and is connected with lenses and bombs of suevite-like and clast and matrix-supported impact breccias. In the resurge breccias quartz with PDFs occurs mainly in the ejected suevite clasts and clast and matrixsupported impact breccias, which were carried back by the resurging wave. The sedimentary rock blocks do not contain PDF-quartz, but it is rarely encountered in the mixtolite-like filling between blocks. In quartz grains, up to five sets of PDFs of different crystallographic orientations have been observed. These confirm shock pressures in excess of 10-14 GPa (Suuroja et al., 2002) or 10-20 GPa (Puura et al., 2004).

In Neugrund, the interior of the crater deep is still buried under post-impact deposits and therefore the most strongly shock-metamorphosed rocks are not accessible there. Suevites, clast and matrixsupported impact breccias that contain quartz with PDFs originate from rocks of the rim wall, from the distal deformed sedimentary target rocks, from the ejecta layer or from the redeposited impactmetamorphic materials as the Osmussaar breccias. Quartz with PDFs on the islands of Osmussaar and Suur-Pakri is found in the veins and bodies of breccia-like limy sandstone (Osmussaar breccia) (Suuroja et al., 2003). We suppose that quartz grains with PDFs of these veins and bodies are eroded from the nearby Neugrund impact structure. PDF-quartz has been found in samples of the submarine crystalline rim wall, and in similar rocks as erratic blocks along the seashore of NW Estonia. Consequently, in this case, the quartz with PDFs has formed in the crystalline basement, which was impact-tectonically transported to form the rim wall.

In quartz grains, up to five sets of PDF-s with different orientations were observed. In a single grain with up to three sets of PDFs were found. The frequency of the lamellae is $200-400$ per $1 \mathrm{~mm}$ and these are frequently decorated with fluid inclusions (Kirsimäe et al., 2002; Suuroja, 2007). The shape and size of the quartz grains with PDFs indicate 
that mainly the impact sedimentary target rocks (Cambrian and Ediacaran silt- and sandstones) have been the source of grains with shock metamorphic signatures and only a small part (angular grains) from the Precambrian metamorphic rocks have contributed.

\section{Discussion and conclusions}

The geological conditions during Cambrian and Ordovician were similar across most part of Baltoscandian platform. A thin sedimentary blanket, merely a few hundred meters thick, under the shallow (less than $200 \mathrm{~m}$ ) epicontinental sea, covered the Precambrian crystalline basement (Männil, 1966; Mens \& Pirrus, 1997). The comparatively large meteorites passed through the water layer and the sedimentary cover and finally exploded in the topmost of the Precambrian crystalline basement.

In Kärdla, we have observed and documented variable degrees of breaking and disintegration of rock bodies, and a variety of their vertical and horizontal transfers during the impact (Puura \& Suuroja, 1984; Puura et al., 1987), and post-impact history (Kleesment et al., 1987; Ainsaar et al., 2002). In the exterior of the crater, within the in-situ broken and mixed target limestone layer, above referred as "limestone breccias", rock debris is abundant, originating from crystalline basement, the alum shale and Cambrian to Ordovician sand, silt and claystones (Suuroja, 2008).

The ring-shaped inner rim of both the Kärdla and Neugrund impact structures, are composed of particularly brecciated and impact-tectonically uplifted blocks (structural uplift) of the Precambrian metamorphic rocks. The Kärdla crater has only one about $1 \mathrm{~km}$ wide quite circular and monolithic crystalline-composed rim wall. Its height is variable, from maximal $250 \mathrm{~m}$ above the primary position (the Paluküla segment on the northeastern part of the rim) to only $50 \mathrm{~m}$ in gullies. The outer wing of the crystalline rim is at least locally overthrusting the Lower Cambrian sandstone strata (Suuroja et al., 1991; Puura and Suuroja, 1992). The latter are most intensely deformed in the near-rim zone, containing also isolated large blocks of crystalline rocks. The target structure in a $4-\mathrm{km}$ wide external zone next to the Paluküla segment of the rim wall is uplifted some tenths meters, and sedimentary rocks are deformed there. The outer limit of the gradually weakening stage of target deformation is fixed by the ring fault of the Kärdla structure (some $12 \mathrm{~km}$ in diameter). At the Neugrund crater, the zone of deformed and a mixed crystalline and sedimentary rock starts at $4 \mathrm{~km}$ from the centre. According to seismic reflection profiling data and scuba diving results, the external c. $6 \mathrm{~km}$ wide zone of dislocations is composed of blocks of the deformed crystalline and sedimentary rocks. The sedimentary blocks are mostly eroded, crystalline are preserved. The ring fault encircling that zone, with a diameter of c. 18 $\mathrm{km}$, is considered as the outer limit of the structure.

In the crater interior, the main impact breccia units have different compositions due to the variety of the source materials. In the Kärdla crater, the lowermost moderately cemented impact breccia unit, here referred to as "clast-supported impact breccias", is composed of dominantly fine-grained debris of crystalline rocks. There is always a portion of Cambrian-type rounded quartz present within it. Randomly, also $\mathrm{mm}$ to $\mathrm{cm}$-size fragments of alum shale are found. In the cement of the breccias, there occurs a large portion of K-feldspar, clay minerals, smectite and in places also chlorite-corrensite. The breccia is, at least partially, hydrothermally altered (Kirsimäe et al., 2002). This breccia is similar to the suevite breccias found in young craters. Thus, we have also called it suevite (Suuroja et al., 2002). However, we cannot confirm the presence of genuine impact melt particles in it. The present mineral association is composed of smectites, chlorites and K-feldspar (Kirsimäe et al., 2002), in which quartz and part of the K-feldspar are the clastic components. recrystallized minerals originate from plagioclase, hornblende, biotite and clay minerals. The latter is derived from Cambrian rocks. Possibly there is a share on unidentified melt particles, too. This kind of breccia is also met at higher levels of the crater infill. In those cases, possibly in a secondary position due to the modification stage slump, resurge and other processes, 
which are followed in the Chesapeak Bay (Gohn et al., 2008), Lockne (Sturkrll et al., 2013) and other impact sites. The middle and upper breccias of the crater interior are mainly dominantly composed of blocks of sedimentary rocks, claystones, sandstones and limestones. The blocks may have huge dimensions, up to tens of meters. Occasionally, in drill sections, a large portion of crystalline blocks may be mixed to the sedimentary dominance. Randomly, also fragments of suevite-like breccias are present. The veins of fine-grained sedimentaryderived cement between the blocks may be of different thickness, often, however, almost negligible.

As a whole, the large masses of sedimentary breccias are composed of primary layered material behaving as a compact substance. They have not been disintegrated into clay or sandy mass, or platy limestone fragments. Therefore we interpret the large volume of dominantly sedimentary-derived block breccias as a product of near-horizontal farand-back replacements during the cratering, slumping and resurge processes. Principally, mixing of materials during the impact process is overwhelming. However, masses originated from certain positions may occasionally dominate here and there in the crater interior. The most homogenous breccia layer is the lowermost crystalline-derived suevitic breccia, with a small but still always observable admixture of Cambrian sand.

As a result, spatial replacement tracks of materials from their primary positions into different breccias or other clastic units in crater interiors and exteriors can be and have been traced. In the circumBaltic area, the other 550-450 My craters are much more deeply eroded, or tectonically deformed (Lockne). In the Lockne case, horizontal movements of rock megablocks have been traced up to $100 \mathrm{~m}$ from the impact center (Sturkell et al., 2000; Ormö \& Lindström, 2000). In Neugrund the, glacial erratic derived from the structure are budged more than $170 \mathrm{~km}$ to southward up to Ruhnu Island (Suuroja, 2008a).

The search for, and discovery of, new buried impact sites in geologically well-studied regions is possible using geophysical, remote sensing, and deep drilling techniques. In Neugrund, the search started with the establishment of the origin of specific gneiss-breccia erratics and of annular depressions on seabed encircling the Neugrund Bank (Suuroja and Saadre, 1995; Suuroja, 1996). In both cases, the discovery of the impact structures was connected with geological mapping (Kala \& Elterman, 1969; Kala et al., 1971; Suuroja et al., 1981, 1987, 1991, 1994, 1997, 1998, 1999). Drillings at Kärdla were mostly carried out in the course of prospecting of mineral resources (e.g. Suuroja et al., 1974; Suuroja, 2002). As a whole, in areas with very stable platform sedimentary structure, all kinds of irregular and odd structural or lithological occurrences: stratigraphic "instabilities", geophysical anomalies, and, of course, findings of shock metamorphic minerals (PDF-quartz) should be treated as suspect phenomena when search for new craters.

Extraordinary stratigraphic and lithological phenomena accompanying impact structures in stratified geological environments attract the attention of researchers for at least two reasons. Distal ejecta layers in well-stratified sedimentary sequences give good opportunities for dating the age of craters. The method worked well in both Kärdla and Neugrund. In the surroundings of the Kärdla impact structure, the ejected matter (sandy layer in limestone sequence) is well traceable within a c. $50-\mathrm{km}$ radius (Suuroja \& Suuroja, 2006). In Neugrund, the ejecta are represented mostly by a sandy layer in a sequence of silt- and sandstones. Thus it is not as well traceable and is therefore exactly determined only due to the occurrence of PDFquartz (Suuroja \& Suuroja, 2000). Often a crater deep have formed traps for early to late post-impact sedimentary accumulation, with uninterrupted course of deposition. In the Kärdla crater, the record of volcanic ash interbeds (K-bentonites) within Ordovician limestone is much more complete than in the surrounding shallow shelf area of repeatedly interrupted low-rate sedimentation. In the shallow zones of the basin outside the rim ridges and uplifted target areas, local erosion and bioherm-type deposition areas occurred (Suuroja \& Suuroja, 2002; Ainsaar et al., 2003). Eroded material from the ejecta blanket and rim wall influenced the post-impact sedimentation in the wider surroundings of the 
crater. The specific lithological suites are distinguished as local litostragraphic units: Kärdla and Paluküla Formations and a number of members (Suuroja et al., 1994; Suuroja, 2008a). In Neugrund, only a distal ejecta layer with PDF-quartz grains has been found. We expect that many surprising stratigraphic, palaeoenvironmental and lithological patterns will be met when coring a drill hole into the Neugrund crater proper.

The size, internal structure and morphology of a crater may carry information about the projectile size, composition and trajectory. Both Kärdla and Neugrund impact structures have ring faults as the outer limits of their impact-deformed areas. Similar features have been observed at some other impact structures: Gosses Bluff, $22 \mathrm{~km}$ in diameter (Milton et al., 1996); Boltysh, $24 \mathrm{~km}$ in diameter (Gurov et al., 1998, 2003); Ries Nördlinger, 24 km in diameter (Engelhardt et al., 1996); Mjølnir, c. 40 $\mathrm{km}$ in diameter (Dypvik et al., 2006). The dimensions of the Neugrund and Kärdla impact structures have been under some discussion. For similar complex impact structures as Kärdla and Neugrund, the diameter of the structure has been defined as the ring fault or by the limit of the structure, thus separating strongly disturbed target rocks from mostly intact target rocks. Following this practice, the diameter of the Neugrund impact structure is c. $18 \mathrm{~km}$ and the one of Kärdla c.12 $\mathrm{km}$, whilte the rim-to-rim diameter of the craters being 7 and $4 \mathrm{~km}$, respectively. Pierazzo \& Melosh (2000) and Shuvalov (2002) concluded that asymmetrical elements of a structure, height and width of a rim wall, elliptical shape of a ring fault etc., refer to oblique impacts. These features are revealed remarkably well in the Kärdla case, where the asymmetrically located ring fault and asymmetry in rim wall height could be explained by an oblique impact (Suuroja \& Suuroja, 2006; Jōeleht et al., 2007) in a layered target (Sturkell et al., 2013). Chemical evidence suggests that the Kärdla projectile was probably of chondritic composition.

The asteroid c. $0.5 \mathrm{~km}$ in diameter approached from southwest (without corrections to plate drift and rotation) under a quite low angle, probably less than $30^{\circ}$. For the complex impact structures such kind of asymmetry in location of an outer and inner crater is quite rare. Exclusively, similar elements of asymmetry are traceable in about 570 My old Shoemaker (or Teague) Ring in Western Australia (Shoemaker \& Shoemaker, 1996). The centre of the $30 \mathrm{~km}$ in diameter complex impact structure is budged about $8 \mathrm{~km}$ to westward concerning of the centre of the inner crater.

\section{Acknowledgements}

The authors are grateful to marine archaeologist Vello Mäss (Estonian Maritime Museum) for his assistance in organizing the marine expedition and scuba diving. Thanks to Väino Puura (University of Tartu) for his helpful advice. Special thanks to the colleagues at the Geological Survey of Estonia for their assistance. Constructive criticism by two anonymous reviewers significantly improved this article. This study has been supported by the Estonian Science Foundation, grants JD172 and ETF8266.

\section{References}

Ainsaar, L., Suuroja, K. \& Semidor, M. 2002. Long-term effects of the Kärdla impact. Pergamon. Deep-Sea Research II 49, 1145-1155.

Alwmark, C. 2009. Shocked quartz grains in the polymict breccia of the Granby structure, Sweden -Verification of an impact. Meteoritics \& Planetary Science 47, 11071113.

Alwmark, C. \& Schmitz, B. 2006. Extraterrestrial Chromite in the Ordovician Lockne Impact Structure, Central Sweden. Proceedings of 69 th Annual Meeting of the Meteoritical Society, held August 6-11, 2006 in Zurich, Switzerland, Meteoritics \& Planetary Science 41, 5056.

Bauert, H., Männil, R. \& Suuroja, K. 1987. The age of the Kärdla crater (in Russian). In: P. Suveidis (ed.) Local structures in Belarus and Baltic Region. Thesis of the meteoritic conference. Geological Research Institute, Vilnius, Lithuanian SSR, pp 48-49.

Crosta, A.P. 2004. Impact Craters in Brazil: How Far We've Got. Research in Terrestrial Impact Structures, pp. 3038.

Dypvik, H., Smelror, M., Sandbakken, P.T., Salvigsen, O. \& Kalleson, E. 2006. Traces of the marine Mjolnir impact event. Palaeogeography, Palaeoclimatology, Palaeoecology 241, 621-636.

Eichwald, E. 1840. Kurze Anzeige einer geognostischen Untersuchung Estlands und einiger Inseln der Ostsee. Die Urwelt Russlands, Heft 1. St.-Petersburg, pp. 1-24.

Englehardt, W., Arndt, J., Fecker, B. \& Pankau, H.G. 1995. Suevite breccia from the Ries crater, Germany: Origin, 
cooling history and devitrification of impact glasses. Meteoritics 30, 279-293.

Flodén, T., Tunander, P. \& Wickman, F.E. 1986. The Tvären Bay structure, an astrobleme in southeastern Sweden. GFF 108, 225-234.

Gohn G.S., Koeberl, C., Miller, K.G., Reimold, W.U., Browning, J.V., Cockell, C.S., Horton Jr, J.W., Kenkmann, T., Kulpecz, A.A., Powars, D.S., Sanford, W.E. \& Voytek, M.A. 2008. Deep drilling into the Cheaspeak Bay Impact Structure. Science 27, 1740-1745.

Grahn, Y., Nôlvak, J. \& Paris, F. 1996. Precise chitinozoan dating of Ordovician impact events in Baltoscandia. Journal of Micropaleontology 15, 21-25.

Gurov, E.P., Koeberl, C. \& Reimold, W.U. 1998. Petrography and geochemistry of target rocks and impactites from Ilynets Crater, Ukraine. Meteoritics \& Planetary Science 33, 1317-1333.

Gurov, E. P., Kelley, S. P. \& Koeberl, C. 2003. Ejecta of the Boltysh Impact Crater in the Ukrainian Shield. In: Koeberl, C. \& Martiney-Ruiz, F. (eds.) Impact Markers in the Stratigraphic Record, Springer-Verlag, Berlin Heidelberg, Impact Studies, 179-202.

Henkel, H. \& Pesonen, L. 1992. Impact craters and craterform structures in Fennoscandia. Tectonophysics 216, 31-40.

Jóeleht, A., Plado, J., Tuuling, 1., Gaškov, M., Rooni, K. \& Tsyroulnikov, A. 2007. Rim morphology of the Kärdla crater based on reflection seismic. Lunar and Planetary Science 38, A 1615.

Kala, E. \& Elterman, G. 1969. Report of the integrated geological mapping of Western Estonia (sheet O-35-XII) at a scale of 1:200 000 (in Russian). Geological Survey of Estonian SSR, Tallinn.

Kala, E., Kajak, K., Kajak, H. \& Elterman, G. 1971. The integrated geological-hydrogeological mapping of Hiiumaa Island (sheet O-34-XI) at a scale of 1:200 000 (in Russian). Map with explanatory note. Geological Survey of Estonian SSR, Tallinn.

Kattai, V., Klubov, B., Kala, E. \& Suuroja, K. 1990. Natural bitumen outcrops on Hiiumaa Island (in Russian). Oil Shale 7, 10-18.

Kenkmann, T., Jahn, A., Scherler, D. \& Ivanov, B. A. 2005. Structure and formation of a central uplift: a case study at the Upheaval Dome impact crater, Utah. In: Kenkmann, T., Hörz, F. \& Deutsch, A. (eds.) Large Meteorite Impacts. Geological Society of America Special Paper 384, 85-115.

Kirs, J., Puura, V., Soesoo, A., Klein, V., Konsa, M., Koppelmaa, H., Niin, M. \& Urtson, K. 2009. The crystalline basement of Estonia: rocks complexes of the Paleoproterozoic Orosirian and Statherian and Mesoproterozoic Calymmian Periods, and regional correlations. Estonian Journal of Earth Sciences 58, 219-228.

Kirsimäe, K., Suuroja, S., Kirs, J., Kärki, A., Polikarpus, M., Puura, V. \& Suuroja, K. 2002. Hornblende alteration and fluid inclusions in Kärdla impact crater, Estonia - evidence for impact-induced hydrothermal activity. Meteoritics \& Planetary Science 37, 449-457.

Kleesment, A.L., Pirrus, E., Suuroja, K. \& Tiirmaa, R. 1987. Geology of the north-eastern slope of the mound of the Kärdla buried crater (in Russian with English summary). Proceedings of the Academy of Sciences of the Estonian SSR, Geology 36, 131-139.

Koeberl, C. 1994. African meteorite impact craters: characteristic and geological importance. Journal of African Earth Sciences 18, 263-295.

Koeberl, C. \& Anderson, R.R. 1996. Manson and company: Impact structures in the United States. Geological Society of America Special Paper 302, 1-29.

Koppelmaa, H., Niin, M. \& Kivisilla, J. 1996. About the petrography and mineralogy of the crystalline basement rocks in the Kärdla crater area, Hiiumaa Island, Estonia. Bulletin of the Geological Survey of Estonia 6, 4-25.

Korochantseva, E.V., Trieloff, M., Lorenz, C.A. Buykin, A.I., Ivanova, M.A., Schwarz, W.H., Hopp, J. \& Jessberger, E. K. 2007. L-chondrite asteroid breakup tied to Ordovician meteorite shower by multiple isochron 40Ar-39Ar dating. Meteoritic \& Planetary Science 42, 113-130.

Lehtovaara, J.J., 1992. Soderfjarden: a Cambrian impact crater in western Finland. Tectonophysics 216, 157-161.

Lindström, M., Floden, T., Puura, V. \& Suuroja, K. 1992. The Kärdla, Tvären and Lockne craters - possible evidences of an Ordovician asteroid swarm. Proceedings of the Estonian Academy of Sciences, Geology 41, 4553.

Lindström, M., Flodén, T., Grahn, Y. \& Kathol, B. 1994. Post impact deposits in Tvärn, a marine Middle Ordovician crater south of Stockholm, Sweden. Geological Magazine 131, 91-103.

indström, M., Sturkell, E.F.F., Törnberg, R. \& Ormö, J. 1996. The marine impact crater at Lockne, central Sweden. GFF 118, 193-206.

Melosh, H.J. 1989. Impact Cratering. A Geologic Process. Oxford University Press.

Mens, K. \& Pirrus, E. 1997. Sedimentary cover: Cambrian. In: Raukas, A. \& Teedumäe, A. (eds.) Geology and mineral resources of Estonia. Estonian Academy Publishers, Tallinn, pp 39-51.

Milton, D.J., Glikson, A.Y. \& Brett,R. 1996. Gosses Bluff - a latest Jurassic impact structure, central Australia. Part 1: geological structure, stratigraphy, and origin. AGSO Journal of Australian Geology \& Geophysics 16, 453486.

Männil, R. 1966. Evolution of the Baltic basin during the Ordovician (in Russian with English summary). Valgus, Tallinn.

Ormö, J. \& Lindström, M. 2000. When cosmic impact strikes the sea bed. Geological Magazine 137, 67-80.

Ormö, J., Rossi, A. \& Housen, K.R. 2013. A new method to determine the direction of impact: Asymmetry of of 
concentric impact craters as observed in the field (Lockne), on Mars, in experiments, and simulations. Meteoritics \& Planetary Science 48, 403-419.

Orviku, K. 1935. Gneissbretša suurte rändrahnude kivimina. Gneissbreccia as a rock of the big erratic boulders (in Estonian). Eesti Loodus 4, 98-99.

Osersky, L. 1844. Geognostischer Umries des Nord-Westlichen Ehstland. Verhandl. d. Russ.- Kaiserl. Mineral. Ges. zu St.-Peterburg.

Palmre, H. 1961. Polümetallide esinemisest ja uurimisest Eesti NSV-s (in Estonian). Eesti Loodus 6, 359-361.

Pesonen, L.J. 1996. The impact cratering record of Fennoscandia. Earth, Moon, Planets 72, 377-393.

Pierazzo, E. \& Melosh, H.J. 2000. Hydrocode modelling of oblique impacts: The fate of the projectile. Meteoritics \& Planetary Science 35, 117-130.

Plado, J., Pesonen, L., Elo, S., Puura., V. \& Suuroja, K. 1996. Geophysical research of the Kärdla impact structure, Hiiumaa Island, Estonia. Metoritics \& Planetary Science 31, 289-298.

Plado, J., Pesonen, L.J. \& Puura, V. 1999. Effects of erosion on gravity and magnetic signatures of complex impact structures: Geophysical modelling and applications. In: Dressler, B., Sharpton, V.L. (Eds.), Large Meteorite Impacts and Planetary Evolution II. Geophysical Society of America, Special Paper 339, 229-240.

Puura, V. 1974. The structure of the southern slope of Baltic Shield (in Russian). PhD thesis. Institute of Geology Academy of Science Estonian SSR. Tallinn.

Puura, V. \& Flodén, T. 2000. The Baltic Sea drainage basin - a model of a Cenozoic morphostructure reflecting the early Precambrian crustal pattern. In: Cato, I. \& Klinberg, F. (eds.) Proceedings of the Fourth Marine Geological Conference "The Baltic," Uppsala 1995, Sveriges Geologiska Undersökning, Research Papers 86, pp 131137.

Puura, V., Huber, H., Kirs, J., Kärki, A., Suuroja, K., Kirsimäe, K., Kivisilla, J., Kleesment, A., Konsa, M., Preeden, U., Suuroja, S. \& Koeberl, C. 2004. Geology, petrography, shock petrography, and geochemisty of impactites and target rocks from the Kärdla crater, Estonia. Meteoritics \& Planetary Science 39, 425-451.

Puura, V., Kala, E. \& Suuroja, K. 1987. The structure of the Kärdla astrobleme (in Russian). Meteoritika 48, 150-161.

Puura,V. \& Plado, J. 2005. Settings of meteorite impact structures in the Svecofennian Crustal Domain. In: Koeberl, C. \& Henkel, H. (eds.) Impact Tectonics. Springer-Verlag Berlin-Heidelberg, pp. 211-245.

Puura, V. \& Suuroja, K. 1984. Kärdla kraater - maapóue varjunud uunikum. Kärdla crater - the buried unic (In Estonian with English summary). Eesti Loodus 8, 553565.

Puura, V. \& Suuroja, K. 1992. Ordovician impact crater at Kärdla, Hiiumaa Island, Estonia. Tectonophysics 216,
$143-156$.

Robertson, P.B. \& Grieve, R.A.F. 1975. Impact structures in Canada: Their recognition and characteristics. Journal of the Royal Astronomical Society of Canada 69, 1-21.

Romano, R. \& Crosta, A.P. 2004. Brazilian Impact craters: A review. Lunar and Planetary Science XXXV.

Schmidt, F. 1858. Untersuchungen über die Siluriche Formation von Ehstland, Nord-Livland und Oesel. Archiv f.d. Naturkunde Liv-, Ehst- und Kurlands, Ser. I, Bd. 2. Dorpat.

Schmitz, B. \& Alwmark, C. 2006. The Lockne Crater, disruption of the chondrite parent body and the great Ordovician biodiversification event. In: Lockne, 2006. Abstract Volume and Program. Impact Craters as Indicators for Planetary Environmental Evolution and Astrobiology. Östersund (Sweden), June 8-14, 2006, pp. $15-16$.

Schmitz, B., Häggström, T. \& Tassinari, M. 2003. Sedimentdispersed extraterrestrial chromite traces a major asteroid disruption event. Science 300, 961-964.

Schmitz, B. \& Häggström, T. 2006. Extraterrestrial chromite in Middle Ordovician marine limestone at Kinnekulle, southern Sweden - traces of a major asteroid breakup event. Meteoritics \& Planetary Science 41, 455-466.

Schrenk, A. 1854. Übersicht des oberen silurischen Schichtensystems Liv- und Ehstlands, vornehmlich ihrer Insel gruppe. Archiv f.d. Naturkunde Liv-, Ehst- und Kurlands, ser.I, Bd. 1. Dorpat.

Scupin, H. 1927. Beiträge zur Geologie der ostbalteischen Länder. 1. Vordevonische Spuren des "Alten Roten Nordlands” im Ostbatikum. Zentralbl. Für Min. Geol. u. Pal., Jahrg. 1927.

Shoemaker, E.M. \& Shoemaker, C.S. 1996. The Proterozoic impact record of Australia. AGSO Journal of Australian Geology \& Geophysics 16, 379-398.

Shuvalov, V. 2002. Numerical Modelling of Impacts into Shallow Sea. In: Plado, J. \& Pesonen, L. (eds.) Impacts in Precambrian Shields. Springer Verlag. Impact Studies, pp 323-336.

Simonds, C.H., Phinney, W., McGee, P. \& Cochran, A. 1978. West Clearwater, Quebec impact structure, Part I: Field geology, structure and bulk chemistry. Proceedings Lunar and Planetary Science Conference 9th, 2633-2658.

Sonett, C.P., Pearce, S.J. \& Gault, D.E. 1991. The oceanic impact of the large objects. Advances in Space Research $11,77-86$

Sturkell, E.F.F., Ormö, J., Nõlvak, J. \& Wallin, A. 2000. Distant ejecta from the Lockne marine-target impact crater, Sweden. Meteoritics \& Planetary Science 35, 929-936.

Sturkell, E.F.F., Ormö, J. \& Lepinette, A. 2013. Early modification stage (preresurge) sediment mobilization in the Lockne concentric, marine target crater, Sweden. Meteoritics \& Planetary Science 48, 321-338.

Suuroja, K. 1996. The geological mapping as a source of 
geological discoveries. Geological mapping in Baltic States. 2nd Newsletter of Geological Surveys of Estonia, Latvia, Lithuania. 1996, 19-22.

Suuroja, K. 2001. Kärdla Meteorite Crater. Geological Survey of Estonia, Tallinn.

Suuroja, K. 2002. Natural Resources of the Kärdla Impact Structure, Hiiumaa Island, Estonia. In: Plado, J. \& Pesonen, L. (eds.) Impacts in Precambrian Shields, Springer Verlag, Berlin-Heidelberg. Impact Studies, 294-306.

Suuroja, K. 2008. Geology and lithology of the early palaeozoic marine impact structures Kärdla and Neugrund (Estonia). Dissertationes Geologicae Universitatis Tartuensis 22.

Suuroja, K., Gromov, O., Kala, E., Gromova, G., Petersell, V. \& Puura, V. 1974. Report of search of crystalline basement uplifts Notheastern Island of Hiiumaa and assessment for production of quality granitic aggregates (in Russia). Geological Survey of Estonia, Tallinn.

Suuroja, K. 2008. Kärdla Meteorite Crater. Monumenta Estonica. GeoTrail. Tallinn.

Suuroja, K., Kadastik, E., Ploom, K. \& Saadre, T. 1998. Geological mapping of North-western Estonia at a scale of 1:50 000/1:25 000. Explanatory note. Geological Survey of Estonia, Tallinn.

Suuroja, K., Kirsimäe, K., Ainsaar, L., Kohv, M., Mahaney, W. \& Suuroja, S. 2003. The Osmussaar Breccia in Northwestern Estonia - Evidence of a ca 475 Ma earthquake or an impact? In: Koeberl, C. \& Martinez-Ruiz, F. (eds.) Impact Markers in the Stratigraphic Record. SpringerVerlag. Berlin-Heidelberg. Impact Studies, pp 333-347.

Suuroja, K., Koppelmaa, H., Kivisilla, J. \& Niin, M. 1987. The deep geological mapping of the Nóva-Haapsalu area at a scale of 1:200 000 (in Russian). Three maps with explanatory note. Geological Survey of Estonian SSR, Tallinn.

Suuroja, K., Koppelmaa, H., Niin, M. \& Kivisilla, J. 1991. Geological mapping of the crystalline basement in Island of Hiiumaa at a scale of 1:200 000 (in Russian). Explanatory note and two maps (crystalline basement, bedrock). Geological Survey of Estonia, Tallinn.

Suuroja, K., Mardim, T., Kadastik, E. \& Elterman, G. 1994. Report of the integrated large scale (1:50 000) geological mapping of Island of Hiiumaa (in Estonian). Maps and explanatory note. Geological Survey of Estonia, Tallinn.

Suuroja, K., Mardla, A. \& Puura, V. 1981. Geological and structural maps of Western Estonia at a scale of 1:200 000 (in Russian). Maps and explanatory note. Geological Survey of Estonian SSR, Tallinn.

Suuroja, K. \& Pôldvere, A. 2002. Description of the Soovälja (K-1) core. In: Pôldvere, A. (ed.) Soovälja (K-1) drill core. Appendix 1. Geological Survey of Estonia, pp. 30-46.

Suuroja, K. \& Saadre, T. 1995. The gneiss-breccia erratic boulders from northwestern Estonia as witnesses of an unknown impact structure. Bulletin of Geological Survey of Estonia 5/1, 26-28.
Suuroja, K. \& Suuroja, S. 1999. Neugrund structure - a submarine meteorite crater at the entrance to the Gulf of Finland. Estonian Maritima 4, 161-189.

Suuroja, K. \& Suuroja, S. 2000. Neugrund Structure - the newly discovered submarine early Cambrian impact crater. In: Gilmour, I. \& Koeberl, C. (eds.) Impacts and the Early Earth. Springer-Verlag, Berlin-Heidelberg. Lecture Notes in Earth Sciences 91, pp 389-416.

Suuroja, K., Suuroja, S., All, T. \& Floden, T. 2002. Kärdla (Hiiumaa Island, Estonia) - the buried and well-preserved Ordovician marine impact structure. Elsvier Pergamon. Deep-Sea Research II 49, 1121-1144.

Suuroja, K., Suuroja, S. \& Puurmann, T. 1997. Neugrund structure an impact crater (in Estonian with English summary). Bulletin of Estonian Geological Society 2/96, $32-41$.

Suuroja, S. 2007. Comparative morphological analyse of the early Paleozoic marine impact structures Kärdla and Neugrund, Estonia. Tallinn University of Technology. TUT Press, PhD Thesis.

Suuroja, S., All, T., Plado, J. \& Suuroja, K. 2002. Geology and Magnetic Signatures of the Neugrund Impact Structure, Estonia. In: Plado, J. \& Pesonen, L. (eds.) Impacts in Precambrian Shields. Springer-Verlag. Impact Studies, 277-294.

Suuroja, S. \& Suuroja, K. 2004. The Neugrund Marine Impact Structure (Gulf of Finland, Estonia). In: Dypvik, H., Burchell, M. \& Claeys, P. (eds.) Cratering in Marine Environments and on Ice. Springer-Verlag, Berlin-Heidelberg. Impact Studies, 75-95.

Suuroja, S. \& Suuroja, K., 2006. Kärdla Impact (Hiiumaa Island, Estonia) - Ejecta Blanket and Environmental Disturbances. In: Cockell, C., Gilmour, I. \& Koeberl, C. (eds.) Biological Processes Associated with Impact Events. Springer-Verlag, Berlin, Heidenberg, New York. Impact Studies 6, 121-146.

Thamm, N. 1933. Über eine Gneisbrekzie im Glazialgeschiebe der Insel Osmussaar (Odensholm). TÜ Geoloogia Instituudi Toimetised 34, 1-14.

Viiding, H. 1955. Eesti NSV rändrahnude petrograafiast. Petrography of the erratic boulders of Estonian SSR (in Estonian). Loodusuurijate Seltsi aastaaruanne 1955, 377389.

Viiding, H., Kala, E. \& Pobul, E. 1969. Paluküla mõistatus laheneb. A mystery of Paluküla find solution (in Estonian). Eesti Loodus 8, 464-474.

Winkler, H. 1922. Eesti geoloogia (in Estonian). Geology of Estonia. Tallinn.

Öpik, A. 1927. Die Inseln Odensholm und Rogö. Ein Beitrag zur Geologie von NW-Estland. Acta et Comm. Univ. Tartuensis. A XII/2. 